\title{
PODSTAWY TRAKTATOWE WOLNOŚCI ŻEGLUGI NA RZEKACH MIEDZYNARODOWYCH Z PERSPEKTYWY MIĘDZYNARODOWEGO PRAWA ZASOBÓW WODNYCH
}

\section{WPROWADZENIE}

Prezentowana niżej problematyka badawcza była przedmiotem szczególnego zainteresowania prof. Bohdana Winiarskiego, który wniósł znaczący wkład w rozwój międzynarodowego prawa rzecznego. Profesor Winiarski był założycielem i pierwszym kierownikiem Katedry Prawa Międzynarodowego na Uniwersytecie Poznańskim w latach 1919-1946, doradca prawnym delegacji polskiej na konferencję pokojową w Paryżu (1919-1920), uczestnikiem konferencji barcelońskiej poświęconej prawu rzecznemu (1921), delegatem Polski w Międzynarodowej Komisji Odry (1923-1931), reprezentantem rządu polskiego przed Stałym Trybunałem Sprawiedliwości Międzynarodowej w sprawie Odry i wreszcie sędzią Międzynarodowego Trybunału Sprawiedliwości w latach 1946-1967, a w latach 1961-1964 jego przewodniczącym ${ }^{1}$. W 2014 r. przypada 130 rocznica urodzin i 45 rocznica śmierci prof. Winiarskiego, który znacząca część swojego zawodowego życia związał z Uniwersytetem. W tym samym roku minie również 85 lat od wydania przez Stały Trybunał Sprawiedliwości Międzynarodowej wyroku w polsko-niemieckim sporze w sprawie Odry ${ }^{2}$. Sprawa ta bardzo dobrze obrazuje główne tendencje rozwojowe międzynarodowego prawa rzecznego od jego początków na przełomie XVIII i XIX w. aż do konwencji i statutu barcelońskiego z 1921 r. Należy podkreślić, że rozwój tego prawa w XIX w. był związany wyraźnie z ideą wolności żeglugi rzecznej. Później, zwłaszcza w drugiej połowie XX w., zaczęło ono regulować także nieżeglugowe wykorzystanie rzek. J. Menkes podkreśla, że zasadnicze zmiany w zakresie sposobów wykorzystywania rzek spowodowały, iż w tej dziedzinie uregulowania międzynarodowe przebyły charakterystyczną drogę: od instytucji rzeki międzynarodowej ustanowionej na potrzeby unormowania wolności żeglugi do instytucji międzynarodowego cieku wodnego, wiążącej się $\mathrm{z}$ jego żeglugowym

1 Sylwetkę Profesora Bohdana Winiarskiego prezentują: J. Sandorski, Bohdan Winiarski. Prawo. Polityka. Sprawiedliwość, Poznań 2004, ss. 152 oraz K. Skubiszewski, Bohdan Winiarski jako sędzia międzynarodowy, „Ruch Prawniczy, Ekonomiczny i Socjologiczny” 1999, z. 3-4, s. 6 i n.

2 Tekst wyroku zob.: Affaire relative à la juridiction territoriale de la Commission internationale de l'Oder (Allemagne et al. c. Pologne), arrêt n 16,1929 , Cour permanente de Justice internationale, série A-n ${ }^{\circ} 23$, s. 31 i n. 
i nieżeglugowym wykorzystaniem ${ }^{3}$. Obrazuja to zwłaszcza postanowienia Konwencji Narodów Zjednoczonych z 21 maja 1997 r. o prawie nieżeglugowego wykorzystania międzynarodowych cieków wodnych ${ }^{4}$ oraz prace Komisji Prawa Międzynarodowego w odniesieniu do zasobów naturalnych dzielonych ${ }^{5}$. Współczesna ewolucja tych uregulowań oznacza stanowienie i rozwijanie regulacji międzynarodowego prawa zasobów wodnych.

Problematyka użytkowania rzek oraz innych wód dzielących terytoria państwowe lub przepływających przez terytoria dwóch lub większej liczby państw od dawna koncentrowała na sobie uwagę doktryny prawa międzynarodowego, była również przedmiotem regulacji normatywnych. Podkreślił to wyraźnie B. Winiarski $\mathrm{w}$ swoim fundamentalnym wykładzie na temat rzek międzynarodowych, wygłoszonym w Akademii Prawa Międzynarodowego w Hadze w 1933 r. Prezentując główne tendencje rozwojowe międzynarodowego prawa rzecznego, stwierdził on: „Znana jest rola, jaką w historii wszystkich cywilizacji odegrały wielkie szlaki wodne [...] rzeki niosa w swych wodach historię i życie narodów [...]. Podczas tych rozważań mogliśmy stwierdzić, że międzynarodowe prawo rzek rozwija się wśród bezustannych starć interesów i idei, ale jednak się rozwija [...]. Nieuwzględnianie realiów, pomijanie różnych etapów równałoby się zaprzepaszczeniu wyników już osiagnniętych oraz możliwości, jakie stawia przed nami przyszłość. Na szczęście międzynarodowe prawo rzeczne płynie swoim biegiem i tak samo niewzruszenie i niezmiennie jak rzeki, które biegną swoim korytem" ${ }^{6}$.

Zrozumiała sprzeczność interesów państw nadbrzeżnych w dziedzinie użytkowania rzek i innych wód powierzchniowych powodowała w przeszłości liczne spory i konflikty międzynarodowe. Wyłączając naturalne spory powstające przy wytyczaniu granic państwowych, były to zwykle spory związane z uprawianiem żeglugi na rzekach jako międzynarodowych drogach wodnych. Do sporów takich dochodziło zwłaszcza wtedy, kiedy państwo położone w dolnym biegu rzeki wykorzystywało swoje uprzywilejowane położenie geograficzne i zabraniało lub utrudniało państwu lub państwom położonym w górnym jej biegu użytkowanie tej drogi wodnej, dającej im dostęp do międzynarodowych szlaków handlowych, zwłaszcza do szlaków morskich.

Problematykę tę zaczęło regulować międzynarodowe prawo rzeczne, które zapoczątkował spór o prawo żeglugi na Skaldzie ${ }^{7}$. J. Menkes pisze obrazowo, że „,nowożytne międzynarodowe prawo rzeczne wyłoniło się z nurtu Skaldy”.

${ }^{3}$ J. Menkes, Ksztattowanie prawa międzynarodowego zasobów wodnych, Warszawa 2000, s. 16.

${ }^{4}$ UN Convention on the Law of the Non-Navigational Uses of International Watercourses, adopted by the General Assembly of the United Nations on 21 May 1997, UNGA Res. 51/229, UN Doc. A/51/8609.

${ }^{5}$ W 2002 r. Komisja Prawa Międzynarodowego rozpoczęła prace nad problematyką: Shared Natural Resources of States (sprawozdawca: Chusei Yamada) 5 sierpnia 2008 r. Komisja przyjęła projekt artykułów konwencji (convention on transboundary aquifers); tekst: UNDoc.A/CN.4/L.724.

${ }^{6}$ B. Winiarski, Principes généraux du droit fluvial international, , Recueil de Cours de l'Académie de droit international de La Haye" 1933-III, s. 84 i 212. (Wszystkie cytaty w tłumaczeniu autora niniejszego artykułu).

${ }^{7}$ Spór ten powstał na tle interpretacji postanowień hiszpańsko-holenderskiego traktatu z Münster, na mocy którego zamknięto Skaldę dla żeglugi, co wywołało zdecydowany sprzeciw Francji; szerzej: J. Gilas, Rzeki w prawie międzynarodowym XIX $i$ XX wieku, w: Rzeki: kultura-cywilizacja-historia, t. 7, Toruń 1968, s. 107 i n.

8 J. Menkes, op. cit., s. 19. 
W odpowiedzi na zamknięcie Skaldy dla żeglugi w dekrecie z 16 listopada 1792 r. Tymczasowa Rada Wykonawcza Konwentu odwołała się do rzymskiej zasady wolności żeglugi jako źródła przekonania o istnieniu normy, zgodnie z którą rzeki żeglowne są wspólną i niepodzielną własnością państw nadrzecznych (rei publicae iure gentium) i jako takie nie mogą być przedmiotem zawłaszczenia ${ }^{9}$. Uważa się, że stanowisko Francji wyrażone w postanowieniach tego dekretu było początkiem nowożytnego prawa rzecznego, które dynamicznie rozwinęło się zwłaszcza w XIX i na początku XX w., a które regulowało status prawny rzek międzynarodowych oraz ich wykorzystywanie do celów handlowych, jak również problematykę wolności żeglugi i tranzytu na tych szlakach wodnych ${ }^{10}$.

\section{WOLNOŚĆ ŻEGLUGI NA RZEKACH MIĘDZYNARODOWYCH - PODSTAWY TRAKTATOWE}

Omawiając źródła wolności żeglugi na rzekach międzynarodowych, B. Winarski podkreśla, że: ,wolność żeglugi międzynarodowej oparta być musi na konkretnym tytule, że tym tytułem nie może być nic innego, jak wyraźna w wyjątkowych wypadkach także domniemana - wola państwa, przez terytorium którego rzeka przepływa"11. W związku z tym autor pisze dalej, że: „,zwykle jednak wolność żeglugi stypulują państwa w umowach, zwanych dalej traktatami handlu i żeglugi [...]. Każda umowa międzynarodowa przyznająca pewnemu państwu lub wielu państwom prawo żeglugi na jakiejś rzece jest jednocześnie stwierdzeniem niewzruszonej zasady zwierzchnictwa państwa, przez którego terytorium rzeka płynie, oraz stwierdzeniem zasady, że prawo żeglugi po obcym terytorium może mieć za podstawę jedynie wolę państwa, terytorialnie zainteresowanego" ${ }^{12}$.

Najważniejsze z tych umów, jako podstawy traktatowe wolności żeglugi na rzekach międzynarodowych, zostaną zaprezentowane niżej.

\section{Traktat paryski}

Właściwy rozwój zasady wolności żeglugi na rzekach międzynarodowych rozpoczął się w traktatach zawieranych po wojnach napoleońskich. Proklamowana wcześniej w dekrecie Tymczasowej Rady Wykonawczej Konwentu zasada

\footnotetext{
${ }^{9}$ Tekst dekretu: Moniteur universel de 1792, n 127-V; zob. też: Ulpian (Dig. lib. XLIII, tit. XIV, s. 1); Iustiniani Institutiones, lib. II, tit. I, § 2 i 5.

10 Samo pojęcie „rzeka międzynarodowa” od dawna było obecne w doktrynie prawa międzynarodowego. Uważa się, że po raz pierwszy w literaturze prawniczej zostało ono użyte w $1879 \mathrm{r}$. przez E. Engelhardta, który pisał: „Le parcours conventionnel d'un fleuve international s'étend de la localité au-delà frontière à partir de laquelle la navigation s'exerce régulièrement jusque dans la mer" (idem, $D u$ régime conventionnel des fleuves internationaux, Paris 1879, s. 69). O kryteriach klasyfikowania rzek międzynarodowych piszą np. A. Gadkowski, Z problematyki międzynarodowego prawa zasobów wodnych, Zeszyty Naukowe WSHiU, t. 25, Poznań 2013; S. Wajda, Klasyfikacja rzek ze stanowiska prawa międzynarodowego, „Przegląd Stosunków Międzynarodowych” 1979, nr 1, s. 107 i n.; idem, Prawo wolności żeglugi rzecznej ze stanowiska prawa międzynarodowego, „Przegląd Stosunków Międzynarodowych" 1979, nr 5, s. 46 i n.

${ }^{11}$ B. Winiarski, Rzeki polskie ze stanowiska prawa międzynarodowego, Poznań 1922, s. 82.

12 Ibidem.
} 
wolności żeglugi znalazła swoje uregulowanie w traktacie paryskim z 30 maja $1814 \mathrm{r}$. Należy podkreślić, że wspomniany dekret nie przewidywał pełnej wolności żeglugi na Skaldzie i Mozie i ograniczał jej wykonywanie tylko do państw nadbrzeżnych ${ }^{13}$. P. Fauchille pisze w związku z tym, że przywilej pierwszeństwa $\mathrm{w}$ tym zakresie przypada postanowieniom traktatu paryskie$\mathrm{go}^{14}$. Przepis jego art. V stanowi, że: ,Żegluga na Renie, od miejsca, w którym staje się on żeglowny, do morza i z powrotem będzie wolna i nie może być zakazana nikomu" ${ }^{15}$. Omawiając postanowienia traktatu paryskiego, J. Menkes podkreśla, że traktat ten stworzył nową instytucję prawa międzynarodowego rzekę międzynarodowa (w aspekcie przedmiotowym), a jego strony uznały za międzynarodową taką rzekę, która swoją drogę wodną dzieli pomiędzy różne państwa albo przez różne państwa przepływa. Cytowany autor dowodzi też, że do paryskiego kryterium uznawania międzynarodowego charakteru rzek odwołuje się w swoich postanowieniach współczesna Konwencji Narodów Zjednoczonych z 1997 r. o prawie nieżeglownego wykorzystania międzynarodowych cieków wodnych, uznająca międzynarodowość cieku wodnego, którego fragmenty znajdują się na terytorium różnych państw ${ }^{16}$.

\section{Akt końcowy kongresu wiedeńskiego}

Koncepcja normatywna rzeki międzynarodowej wypracowana w traktacie paryskim stała się podstawą postanowień art. 108 i 109 Aktu końcowego kongresu wiedeńskiego z 9 czerwca 1815 r. Postanowienia art. 109, fundamentalne z punktu widzenia niniejszych rozważań, stanowią, że: „Żegluga na całym biegu rzek oznaczonych w poprzednim artykule od miejsca, w którym każda z nich staje się żeglowna, aż do jej ujśsia będzie zupełnie wolna i nie będzie mogła być, jeśli chodzi o potrzeby handlu, nikomu wzbroniona, jednakże z zastrzeżeniem przestrzegania odpowiednich przepisów porządkowych, które będą ujęte jednolicie dla wszystkich, w sposób możliwie sprzyjający handlowi wszystkich państw"17.

Analiza postanowień Aktu końcowego kongresu wiedeńskiego pozwala na sformułowanie dwóch najważniejszych wniosków odnośnie do wolności żeglugi rzecznej:

1) państwa, których obszary oddziela lub przecina ta sama rzeka żeglowna, są obowiązane do uporządkowania za wspólną zgodą spraw związanych z żeglugą na tej rzece;

2) żegluga na rzekach oddzielających lub przecinających obszary dwóch lub więcej państw powinna być udostępniona wszystkim narodom w całym biegu rzeki aż do ujścia; przepisy policyjne dotyczące żeglugi powinny być

\footnotetext{
${ }^{13}$ Podobne do francuskiego było stanowisko Stanów Zjednoczonych, które znalazło wyraz w słynnej instrukcji T. Jeffersona z 1792 r., a dotyczyło negocjacji z Hiszpanią w sprawie żeglugi na Missisipi; J. B. Moore, A Digest of International Law, Washington 1906, par. 130-624, 631-633.

${ }_{14}$ P. Fauchille, Traité de droit international public, t. 1, cz. 2, Paris 1921-1925, s. 465.

15 Tekst traktatu: C. Parry (red.), The Consolidated Treaty Series, vol. 63(1813-1815), New York 1969 , s. 171-191.

16 J. Menkes, op. cit., s. 22.

17 Tekst traktatu zob. C. A. Colliard, Droit international et histoire diplomatique, Paris 1948, s. 100; tekst polski: B. Winiarski, Wybór źródet do nauki prawa międzynarodowego, Warszawa 1938, s. 7.
} 
ułożone w sposób jednolity i w miarę możności korzystny dla handlu wszystkich narodów ${ }^{18}$.

Jak już wskazałem wyżej, postanowienia te są uważane za podstawę rozwoju instytucji międzynarodowego prawa rzecznego $\mathrm{w}$ XIX w. i w opinii wielu autorów stanowią swego rodzaju pactum de contrahendo. Są też one nazywane traités-lois, stają się bowiem źródłem konkretnych umów międzynarodowych zwanych traités-contrats ${ }^{19}$.

Z postanowień art. 109 niektórzy autorzy wyciagają wniosek, że na kongresie wiedeńskim została ustanowiona wolność żeglugi na rzekach międzynarodowych dla wszystkich państw. Tak twierdzi np. L. Gelberg, który uważa, że ,,artykuły 108-117 Aktu końcowego Kongresu Wiedeńskiego z 1815 roku w sprawie rzek międzynarodowych ustanawiały wolność żeglugi dla wszystkich państw pod warunkiem przestrzegania warunków porządkowych" ${ }^{20}$. Również według W. Góralczyka ,prawo wiedeńskie uznawało powszechną wolność żeglugi, a więc nie tylko dla państw nadbrzeżnych, ale dla wszystkich państw" ${ }^{21}$. Szczegółowa analiza postanowień Aktu końcowego odnoszących się do żeglugi na rzekach międzynarodowych nie uzasadnia jednak takiego stanowiska. $\mathrm{Z}$ treści art. 109 nie można bowiem wyciągać wniosku o ustanowieniu powszechnej wolności żeglugi dla wszystkich państw, jako że należy go interpretować w kontekście innych postanowień, a zwłaszcza art. 108. Z obu tych artykułów wynika, że Akt końcowy nie ustanawiał norm, które miały automatycznie obowiązywać sygnatariuszy, a tylko zobowiązywał ich do podjęcia negocjacji w celu uregulowania za wspólna zgodą wszystkich spraw dotyczących żeglugi na rzece. W związku z tym K. Równy pisze, że Akt końcowy ograniczył się tylko do zalecenia wolności żeglugi na rzekach międzynarodowych jako zasady wykorzystywanej przy zawieraniu późniejszych umów pomiędzy państwami ${ }^{22}$. Autor ten akceptuje więc pogląd B. Winiarskiego sformułowany w wykładzie haskim z 1933 r., że ,zasady sformułowane w art. 109-116 miały jedynie znaczenie dyrektyw, do których osiem mocarstw zobowiązało się dostosować; dyrektywy te jednak potrzebowały swego wyrażenia $\mathrm{w}$ konwencjach specjalnych"23.

Do Aktu końcowego kongresu wiedeńskiego dołączono regulamin zawierający szczegółowe postanowienia w sprawie żeglugi na Renie, Nekarze, Menie, Mozie i Skaldzie, przy czym szczegółowo uregulowano jedynie żeglugę na sieci rzecznej Renu. Nie oznacza to jednak, że art. 117 ustanowił powszechną wolność żeglugi na Renie, wolność ta bowiem była ograniczona do statków państw nadreńskich. Taki stan rzeczy potwierdziła późniejsza konwencja moguncka z 1831 r. Nawet konwencja mannheimska z 1868 r., która wprowadziła wolność żeglugi na Renie dla bander wszystkich państw, zachowała w dalszym ciagu przywileje dla statków należących do żeglugi reńskiej ${ }^{24}$. Natomiast poza Europa

\footnotetext{
${ }_{18}$ M. Muszkat (red.), Zarys prawa międzynarodowego publicznego, t. 1, Warszawa 1955, s. 236-237.

19 Z. Izdebski, Rzeka Odra. Zagadnienie prawa narodów, Katowice 1946, s. 13.

${ }^{20}$ L. Gelberg, Zarys prawa międzynarodowego, Warszawa 1977, s. 177.

${ }^{21}$ W. Góralczyk, Prawo międzynarodowe publiczne w zarysie, Warszawa 1977, s. 184.

${ }^{22}$ K. Równy, op. cit., s. 49.

${ }^{23}$ B. Winiarski, Principes générales..., s. 87.

${ }^{24}$ B. Winiarski, Rzeki polskie..., s. 184-185.
} 
wolność żeglugi dla wszystkich państw wprowadzona została na rzekach Kongo i Niger na podstawie postanowień Aktu generalnego kongresu berlińskiego z 1885 r. Rozwiązanie to zostało następnie potwierdzone przez konwencję z Saint-Germain-en-Laye z 1919 r. ${ }^{25}$

\section{Traktat wersalski}

Państwa zwycięskie w I wojnie światowej, które chciały sobie zapewnić szeroki dostęp do rynku surowców i towarów, zdecydowane były wprowadzić wolność żeglugi dla statków handlowych wszystkich państw na możliwie największej liczbie rzek europejskich. Zamierzenie to dotyczyło nie tylko rzek oddzielających lub przepływających przez terytoria różnych państw, lecz także rzek, które w całości znajdowały się na terytorium jednego państwa. Ta ostatnia uwaga dotyczy próby umiędzynarodowienia Wisły oraz jej dopływów - Bugu i Narwi. Wersalski Traktat pokoju z 28 czerwca 1919 r. miał za zadanie przede wszystkim uregulować na nowo stosunki pomiędzy państwami zwycięskimi i zwyciężonymi ${ }^{26}$. Oprócz tego traktat ten zawiera wiele postanowień mających charakter ogólnych norm prawa międzynarodowego. Do takich przepisów należy cała część XII, zatytułowana: „Porty, drogi wodne i drogi żelazne". Postanowienia te zostały przygotowane przez Komisję do spraw Międzynarodowego Ustroju Portów, Dróg Wodnych oraz Dróg Żelaznych. W trakcie prac tej Komisji wypłynęła m.in. sprawa umiędzynarodowienia Wisły, podniesiona przez delegata Czechosłowacji, który domagał się również tego, aby jego państwo miało w Gdańsku port macierzysty dla swoich okrętów ${ }^{27}$. Na skutek zdecydowanej postawy przedstawiciela Polski w Komisji sprawa umiędzynarodowienia Wisły nie pojawiła się w końcowym projekcie traktatu ${ }^{28}$.

Polska została jednak zmuszona do ustępstwa w tej sprawie. Umiędzynarodowienie Wisły zostało bowiem zapisane w postanowieniach art. 18 Traktatu między głównymi mocarstwami sprzymierzonymi i stowarzyszonymi a Polska z 28 czerwca 1919 r. (tzw. traktat mniejszościowy) ${ }^{29}$. Przyjęcie przez Polskę tego traktatu było warunkiem dopuszczenia jej do podpisania Traktatu pokoju z Niemcami (traktat wersalski). Dlatego Polska zgodziła się na przyjęcie postanowień traktatu mniejszościowego, którego art. 18, tworzący tymczasowy stan rzeczy, stanowił: „Dopóki nie nastąpi zawarcie Konwencji ogólnej co do urządzenia międzynarodowego dróg wodnych, Polska zobowiązuje się stosować do systemu rzecznego Wisły (włączając $\mathrm{w}$ to Bug i Narew) porządek, określony w artykułach 332 do 337 Traktatu Pokoju z Niemcami dla międzynarodowych

25 Pisze o tym K. Równy, op. cit., s. 84-85.

${ }^{26}$ Dz. U. RP 1920, Nr 35, poz. 200.

${ }^{27}$ B. Winiarski, Rzeki polskie..., s. 10. Podobne żądanie delegata Czechosłowacji dotyczyło portu w Hamburgu.

${ }^{28}$ Krytykę stanowiska czechosłowackiego w stosunku do Polski przeprowadza np. Z. Izdebski, op. cit., s. 19 i n. Inicjatywę umiędzynarodowienia Wisły przypisuje on nie tylko Czechosłowacji, ale przede wszystkim Wielkiej Brytanii. Bardzo obszernie zagadnienia te analizuje również B. Winiarski, Rzeki polskie..., s. 15 i n.

${ }^{29}$ Tekst tzw. traktatu mniejszościowego z 1919 r.: Dz. U. RP 1920, Nr 110, poz. 728. 
dróg wodnych" ${ }^{30}$. Polska zawsze konsekwentnie broniła narodowego charakteru Wisły i jej dopływów. Powoływała się przy tym również na postanowienia art. 97 traktatu wersalskiego, który oddawał jej na całym odcinku Wisły „zupełną i całkowitą władzę nad rzeką".

Problematyka umiędzynarodowienia rzek została uregulowana w art. 331 traktatu wersalskiego, według którego za międzynarodowe uznano następujące rzeki: Łabę od ujścia Wełtawy, Wełtawę do Pragi, Odrę od ujścia Opawy, Niemen od Grodna, Dunaj od Ulmu oraz wszystkie żeglowne części tych sieci rzecznych, które dają naturalny dostęp do morza więcej niż jednemu państwu, a także kanały boczne i łącznikowe, które będą zbudowane w celu ulepszenia żeglownych $\mathrm{z}$ natury części tych sieci rzecznych bądź połączenia dwóch żeglownych z natury części tej samej rzeki ${ }^{31}$. Status niektórych z tych rzek, np. Dunaju, został następnie szczegółowo określony w innych umowach międzynarodowych ${ }^{32}$.

Gdy chodzi o szczegółową problematykę wolności żeglugi w postanowieniach traktatu wersalskiego, należy powołać postanowienia art. 332, które stanowią, że: „Na drogach uznanych $\mathrm{w}$ artykule poprzednim za międzynarodowe, obywatele, rzeczy i bandery wszystkich Mocarstw będą traktowane na podstawie zupełnej równości, tak aby nie czyniono żadnych różnic na niekorzyść obywateli, rzeczy i bander któregokolwiek z tych Mocarstw, pomiędzy nimi a obywatelami, rzeczami i banderami samego państwa nadbrzeżnego lub państwa, którego obywatele, rzeczy i bandery korzystaja $\mathrm{z}$ największego uprzywilejowania". Ta wolność żeglugi ograniczona jest przez postanowienia art. 332 ust. 2 na niekorzyść Niemiec w ten sposób, że ,jednak statki niemieckie nie będą mogły uprawiać przewozu liniami regularnymi podróżnych i towarów pomiędzy portami jednego i tego samego Mocarstwa sprzymierzonego lub stowarzyszonego bez specjalnego na to z jego strony zezwolenia".

Oceniając wersalski reżim wolności żeglugi rzecznej, należy zauważyć, że istotnym osiągnięciem tych regulacji było wprowadzenie pojęcia „droga wodna” (fr. voie d'eau, ang. waterway). Z drugiej jednak strony ani $\mathrm{w}$ art. 331, ani w innych artykułach rozdz. XII odnoszących się do umiędzynarodawianych rzek nie jest używana wyraźna formuła wolności żeglugi. Jak wskazałem wyżej, art. 332 stwierdza jedynie, że „obywatele, rzeczy i bandery wszystkich Mocarstw będa traktowane na podstawie zupełnej równości”. W związku z tym K. Równy uważa, że twórcy traktatu wersalskiego wyszli prawdopodobnie z założenia, iż samo umiędzynarodowienie rzeki oznacza proklamowanie na niej wolności żeglugi ${ }^{33}$. Kolejna ocena postanowień traktatu związana jest $\mathrm{z}$ ich

${ }^{30}$ Rozciągnięcie tych postanowień na Wisłę było niekorzystne dla Polski. Wisła przepływała bowiem przez niewielki obszar Wolnego Miasta Gdańska, które nie było jednak państwem (np. prowadzenie spraw zagranicznych należało do Polski), a oba jej dopływy (Bug i Narew) nie przecinały ani nie oddzielały terytoriów dwóch lub więcej państw, ponieważ całkowicie znajdowały się na terytorium Polski; zob. B. Winiarski, Rzeki polskie..., s. 177.

${ }^{31}$ Przykład Odry szczegółowo analizuje A. Gadkowski, A propos de la liberté de navigation sur les fleuves internationaux: L'affaire de l'Oder devant la Cour permanente de Justice internationale, „Adam Mickiewicz University Law Review" 2, 2013, s. 248 i n.

${ }^{32}$ Dunaj: konwencja paryska z 23 lipca 1921 r., tekst: LNTS, vol. XXVI, s. 183. Art. 1 tej konwencji ustanawiał wolną żeglugę na Dunaju na warunkach całkowitej równości dla wszystkich państw.

${ }^{33}$ K. Równy, op. cit., s. 59. 
tymczasowością. Artykuł 338 (podobnie jak art. 18 tzw. małego traktatu wersalskiego odnośnie do Wisły) tworzy stan tymczasowości i przewiduje zastapienie postanowień odnoszących się do umiędzynarodowionych rzek przez przyszłą konwencję ogólną dotyczącą dróg żeglownych. Konwencja taka miała być ustanowiona przez mocarstwa sprzymierzone i stowarzyszone oraz zatwierdzona przez Ligę Narodów.

\section{System konwencji barcelońskiej}

W 1921 r. z inicjatywy Ligi Narodów została zwołana do Barcelony konferencja dyplomatyczna w celu wynegocjowania i podpisania zapowiedzianej w traktacie wersalskim konwencji. Przedmiotem obrad konferencji były projekty przygotowane przez Komisję Komunikacji i Tranzytu, której bardzo aktywnym członkiem był prof. Winiarski. Podpisana 20 kwietnia $1921 \mathrm{r}$. konwencja barcelońska była prawdziwą kodyfikacja międzynarodowego prawa rzecznego i była ona - według B. Winiarskiego - „o wiele donioślejsza od dotychczasowych traktatów i konwencyj w tej dziedzinie" ${ }^{34}$. Formalnie rzecz biorąc, konwencja barcelońska składa się z dwóch części, którymi są: Konwencja i Statut w sprawie urządzenia dróg żeglownych o znaczeniu międzynarodowym $^{35}$ oraz Konwencja i Statut o wolności tranzytu ${ }^{36}$. Dokumenty te podpisane zostały 20 kwietnia $1921 \mathrm{r}$.

Interesujące nas z punktu widzenia problematyki wolności żeglugi rzecznej Konwencja i Statut w sprawie urządzenia dróg żeglownych o znaczeniu międzynarodowym stanowią realizację zalecenia kongresu wiedeńskiego, zmierzającego do wprowadzenia powszechnej wolności żeglugi dla wszystkich państw, jak również zapowiedzianego $\mathrm{w}$ art. 338 traktatu wersalskiego uchwalenia konwencji ogólnej dotyczącej dróg żeglownych o znaczeniu międzynarodowym.

Należy podkreślić, że obecność przedstawicieli państw nienadbrzeżnych na konferencji barcelońskiej spowodowała, iż silna była tendencja zmierzająca do objęcia projektowaną konwencją wszystkich żeglownych dróg wodnych, łącznie z tymi, które przebiegaja na terytorium tylko jednego państwa, jak również do rozszerzenia zasady wolności żeglugi na takich drogach wodnych dla wszystkich państw. Większość uczestników konferencji sprzeciwiła się jednak przyjęciu takiej ogólnej formuły powszechnej wolności żeglugi oraz jej stosowaniu w odniesieniu do wszystkich odcinków żeglownych dróg wodnych znajdujących się pod zwierzchnictwem różnych państw. Efektem starcia koncepcji umiędzynarodowienia wszystkich dróg żeglownych z koncepcją znacznie większej grupy państw broniących swojej suwerenności nad narodowymi drogami wodnymi był kompromis, wypracowany ze znaczącym udziałem delegacji polskiej ${ }^{37}$.

${ }^{34}$ B. Winiarski, Rzeki polskie..., s. 88.

35 Tekst: Convention et Statut sur le régime des voies navigables d'intérêt international, Barcelone, 20 avril 1921, LNTS, vol. VII, n 172; tekst polski: B. Winiarski, Wybór źródet..., s. 292 i n.

36 Tekst: Convention et Statut sur la liberté du transit, Barcelone, 20 avril 1921, LNTS, vol. VII, $\mathrm{n}^{\circ}$ 171; tekst polski: Dz. U. RP 1925, Nr 34, poz. 236 i 237.

${ }^{37}$ Piszą o tym K. Równy, op. cit., s. 63 i B. Winiarski, Rzeki polskie..., s. 63. 
Regulacje barcelońskie odchodza od terminu „rzeka międzynarodowa” i wprowadzają pojęcie „drogi żeglowne o znaczeniu międzynarodowym” (fr. voies navigables d'intérêt international, ang. navigable waterways of international concern), do których stosują się ich postanowienia ${ }^{38}$. Zgodnie z postanowieniami art. 1 Statutu pojęcie to oznacza: „Wszystkie z natury w kierunku do morza i od morza żeglowne części drogi wodnej, która w swym biegu z natury żeglownym w kierunku do morza i od morza przedziela lub przecina różne Państwa, jak też każdą część innej drogi wodnej z natury żeglownej w kierunku do morza i od morza, która łączy z morzem drogę wodna z natury żeglowną i przedzielającą lub przecinającą różne Państwa [...]. Drogi wodne, lub części dróg wodnych, naturalne lub sztuczne, uznane wyraźnie jako mające podlegać przepisom konwencji ogólnej w sprawie dróg żeglownych, a to bądź przez akty jednostronne Państw, pod których zwierzchnictwem lub władzą te drogi wodne lub części dróg wodnych się znajdują, bądź przez umowy zawarte z udziałem tych przede wszystkim Państw".

$\mathrm{W}$ związku z tą definicją nasuwają się następujące uwagi. Obejmuje ona tylko „,wszystkie z natury żeglowne w kierunku do morza i od morza części drogi wodnej”. Oznacza to, że definicja ta stosuje się - zgodnie z art. 1 pkt 1b Statutu do „,każdej naturalnej drogi wodnej lub części naturalnej drogi wodnej, na której zwykła żegluga handlowa istnieje obecnie lub może istnieć ze względu na jej przyrodzone warunki”. Oznacza to a contrario, że definicja drogi żeglownej o znaczeniu międzynarodowym nie obejmuje dróg wodnych sztucznie zbudowanych lub takich, które mogą być zbudowane w przyszłości ${ }^{39}$.

Interpretacja konwencji barcelońskiej wymaga również wyjaśnienia formuły żeglowności ,vers et depuis la mer”, o której mowa w art. 1 Statutu. Chodzi mianowicie nie tylko o to, aby taka droga wodna oddzielała lub przecinała terytoria różnych państw, lecz także aby miała połączenie z morzem. Użycie tej formuły w Statucie miało ponadto na celu oznaczenie punktu, od i do którego dana droga żeglowna jest uznana za międzynarodowa. Formuła „do morza” (vers la mer) zmierza do określenia, że wolność żeglugi na rzekach międzynarodowych dotyczy przejścia przez morze terytorialne na morze otwarte i na odwrót ${ }^{40}$. Wyrażenie ,od morza” (depuis la mer) oznacza natomiast miejsce, od którego rzeka staje się żeglowna w jej górnym biegu.

Zasadę wolności żeglugi na drogach wodnych o znaczeniu międzynarodowym proklamuje art. 3 Statutu, zgodnie z którym: „Z zastrzeżeniem postanowień artykułów 5 i 17 każde z układających się Państw przyzna okrętom i statkom płynącym pod bandera któregokolwiek z układających się Państw wolność wykonywania żeglugi na częściach wyżej określonych dróg żeglownych, podległych jego zwierzchnictwu lub władzy". Z treści tego artykułu wynika więc, że proklamowana $\mathrm{w}$ nim wolność żeglugi na drogach żeglownych o znaczeniu międzynarodowym nie dotyczy wszystkich państw, ale tylko jej sygnatariuszy. Oznacza to mniejszy zakres podmiotowy wolności żeglugi niż

${ }^{38}$ Zob. np. A. Bonde, Traité élémentaire de droit international public, Paris 1926, s. 175.

${ }^{39}$ K. Równy, op. cit., s. 64.

40 Zamierzeniem twórców konwencji była chęć uniknięcia kontrowersji wokół interpretacji art. 1 załącznika 16b Aktu końcowego kongresu wiedeńskiego w sprawie przepisów żeglugi na Renie; zob. B. Winiarski, Rzeki polskie..., s. 130. 
ten, który wynika z wcześniejszych regulacji międzynarodowych odnoszących się do takich rzek, jak np. Ren, Dunaj, Niger i Kongo. Nadto formuła z art. 3 oznacza odstępstwa (nawet dla państw sygnatariuszy) od zasady pełnej wolności żeglugi, wynikającej z art. 5 i 17 Statutu. Artykuł 5 zastrzega uprawianie małego i dużego kabotażu na podlegającym państwu odcinku drogi wodnej tylko dla statków własnej bandery z nieznaczną koncesją na rzecz statków obcych bander. Natomiast art. 17 wyłącza korzystanie z wolności żeglugi przez obce okręty wojenne czy statki wykonujące $\mathrm{z}$ jakiegokolwiek tytułu władzę publiczna. Uważa się jednak, że wskazane wyjątki nie podważają znaczenia samej zasady wolności żeglugi na drogach żeglownych o znaczeniu międzynarodowym, sformułowanych w art. 3 Statutu.

Oceniając konwencję barcelońską, należy stwierdzić, że ta pierwsza próba ogólnej kodyfikacji międzynarodowego prawa rzecznego nie doprowadziła do powstania powszechnie obowiązujących norm w kwestii wolności żeglugi na rzekach międzynarodowych. Pośrednio wynika to stąd, że nie ustanowiła ona również takiej powszechnej wolności tranzytu statków na drogach żeglownych o znaczeniu międzynarodowym ${ }^{41}$, mimo że w literaturze słusznie uznaje się tę konwencję i statut za doniosły krok na drodze rozwoju międzynarodowego prawa rzecznego ${ }^{42}$.

Konwencja barcelońska nigdy nie uzyskała charakteru regulacji uniwersalnej. Wśród licznych państw, które jej nie ratyfikowały, jest również Polska. Bogdan Winiarski pisze o tym w kontekście umiędzynarodowienia Odry na podstawie postanowień traktatu wersalskiego ${ }^{43}$. Argumentuje on, że gdyby Polska przystąpiła do konwencji barcelońskiej, dwie rzeki polskie: Warta i Noteć (dopływy Odry), w całym swym biegu z natury żeglownym, a powyżej części umiędzynarodowionych (zgodnie $\mathrm{z}$ art. 331 traktatu wersalskiego) zostałyby zaliczone do kategorii rzek o znaczeniu międzynarodowym, a więc otwartych dla żeglugi. J. Makowski pisze wręcz, że „Konwencja nie obowiązuje Polski, ponieważ jako szkodliwa dla jej interesów nie została przez nią ratyfikowana" ${ }^{44}$. Miało to istotne znaczenie dla wyroku Stałego Trybunału Sprawiedliwości Międzynarodowej w sprawie Odry ${ }^{45}$.

\section{WOLNOŚĆ ŻEGLUGI NA RZEKACH MIĘDZYNARODOWYCH - PODSUMOWANIE}

Jak stwierdziłem wyżej, analiza regulacji traktatowych z zakresu międzynarodowego prawa rzecznego upoważnia do wyrażenia poglądu, że nie ustanowiły one powszechnej zasady wolności żeglugi i tranzytu dla statków

${ }^{41}$ K. Równy, op. cit., s. 71.

${ }^{42}$ B. Winiarski, Principes généraux..., s. 92.

${ }^{43} \mathrm{O}$ umiędzynarodowieniu Odry obszernie pisze S. Wajda, Międzynarodowy status Odry w okresie międzywojennym a stanowisko Polski, „Przegląd Stosunków Międzynarodowych” 1977, nr 1, s. 16 i n.; idem, Z historii prawnomiędzynarodowej Odry, w: J. Gilas, S. Wajda (red.), Status prawnomiędzynarodowy Odry, Opole 1982, s. 15 i n.

${ }^{44} \mathrm{Na}$ temat stosunku Polski do Konwencji zob. J. Makowski, Prawo międzynarodowe publiczne, Warszawa 1930, s. 195.

${ }^{45}$ Omówienie wyroku: zob. np. A. Gadkowski, A propos de la liberté de navigation..., s. 258 i n.; S. Wajda, Międzynarodowy status Odry..., s. 21 i n. 
handlowych różnych państw na wszystkich rzekach międzynarodowych. Ewolucja tych regulacji traktatowych pozwala stwierdzić jedynie, że zasada wolności żeglugi dla statków handlowych wszystkich państw została ustanowiona tylko na niektórych europejskich czy afrykańskich rzekach międzynarodowych.

Powstaje w związku z tym bardzo ważne pytanie: Czy taka powszechna wolność żeglugi na wszystkich rzekach międzynarodowych wynika $\mathrm{z}$ norm zwyczajowych prawa międzynarodowego? W doktrynie znajdujemy niewielu autorów odpowiadających twierdząco na to pytanie ${ }^{46}$. W związku $\mathrm{z}$ tym K. Równy stwierdza, że poglądy takie można traktować jako „reminiscencje starej grocjuszowskiej koncepcji nieszkodliwego przejścia, bądź innych naturalistycznych koncepcji wolności żeglugi” ${ }^{47}$. Jednym z najczęściej powoływanych autorów reprezentujących taki pogląd jest B. K. J. Vitanyj, który wywodzi zwyczajową normę wolności żeglugi na rzekach międzynarodowych, przede wszystkim europejskich, z rozwoju regulacji traktatowych, a zwłaszcza z traktatów pokoju zawartych po I wojnie światowej ${ }^{48}$.

Trudno jednak uznać, że traktaty te kończą proces formowania się normy zwyczajowej dotyczącej wolności żeglugi na rzekach międzynarodowych w Europie. Gdy chodzi o problematykę wolności żeglugi rzecznej, stanowiły one tylko regulację przejściową, która miała zostać zastapiona konwencją ogólną. Konwencja barcelońska, którą zaprezentowałem wyżej, aby mogła być uznana za umowę kończącą proces ustanawiania zwyczaju międzynarodowego w omawianym zakresie, musiałaby spełniać elementarny warunek, jakim byłoby potwierdzenie stałej i jednolitej praktyki państw. Konwencja tego warunku jednak nie spełniała, o czym świadczy choćby wskazany wyżej ograniczony zakres podmiotowy jej stosowania. Ponadto statut barceloński w art. 3 obejmuje tylko swych sygnatariuszy i tylko na zasadzie wzajemności. Świadczy to o istotnym zawężeniu przez prawo barcelońskie zakresu stosowania zasady wolności żeglugi, przez wyłączenie z niej państw niebędących jego stronami. Dodać należy, że równie istotnym zawężeniem stosowania zasady wolności żeglugi jest $\mathrm{w}$ prawie barcelońskim ograniczenie jej tylko do naturalnych żeglownych dróg wodnych mających połączenie z morzem. Zapowiedziana więc przez traktat wersalski konwencja ogólna wcale nie obejmuje wszystkich rzek międzynarodowych i nie proklamuje powszechnej wolności żeglugi rzecznej. $\mathrm{Z}$ tego względu nie można konwencji barcelońskiej ani statutu barcelońskiego traktować jako regulacji zamykających proces formowania się zwyczajowej normy powszechnej wolności żeglugi na europejskich rzekach międzynarodowych ${ }^{49}$. Dla poszczególnych rzek, takich jak Ren czy Dunaj, ustanawiane były

${ }^{46}$ Przegląd poglądów doktryny w tym zakresie zob. np. S. Wajda, Prawo wolności żeglugi rzecznej ze stanowiska prawa międzynarodowego, „Przegląd Stosunków Międzynarodowych” 1979, nr 5, s. 47 i n.

${ }^{47}$ K. Równy, op. cit., s. 81.

${ }^{48}$ B. K. J. Vitanyj, The Regime of Navigation on International Waterways, ,The Netherland Yearbook of International Law" 5, 1974, s. 161 i n.

${ }^{49} \mathrm{~W}$ późniejszej praktyce międzynarodowej podstawowe rozwiązania konwencji barcelońskiej zostały uwzględnione w pewnym zakresie w tzw. regułach helsińskich dotyczących wykorzystywania wód rzek międzynarodowych, przyjętych na 52 Konferencji Stowarzyszenia Prawa Międzynarodowego (ILA) w 1966 r. Wynika z nich, że prawo międzynarodowe nie gwarantuje prawa swobodnej żeglugi statkom należącym do państw innych niż nadbrzeżne, natomiast te ostatnie maja swobodę żeglugi po rzece międzynarodowej, z zachowaniem swobód korzystania z rzeki na całej jej długości, z portów i innych 
odrębne regulacje prawne, na podstawie których powoływano odpowiednie komisje międzynarodowe ${ }^{50}$.

Jak wspomniałem wyżej, w zakresie omawianej problematyki badawczej można zauważyć wyraźną ewolucję kategorii normatywnych, prowadzącą od instytucji rzek międzynarodowych do systemu cieków wodnych i dalej - do międzynarodowego prawa zasobów wodnych. J. Menkes pisze nawet w związku $\mathrm{z}$ tym, że międzynarodowe prawo rzeczne przeszło $\mathrm{w}$ tym okresie drogę analogiczną z prawem morza ,,doby Grocjańskiej” - od systemu normatywnego regulującego reżim prawny powierzchni wody i ruch na drodze wodnej do systemu prawa zasobów międzynarodowych ${ }^{51}$. Formułując taką analogię, należy jednak pamiętać o tym, że międzynarodowe prawo żeglugi rzecznej różni się w sposób istotny od międzynarodowego prawa żeglugi morskiej. W międzynarodowym prawie morza wykształciła się norma zwyczajowa przewidująca wolność żeglugi na morzu pełnym, natomiast norma taka w międzynarodowym prawie rzecznym ma wyłącznie umowne pochodzenie. $Z$ tego względu J. Pieńkos uważa, że prawo rzeczne zbliżone jest bardziej do prawa lotniczego, które istnieje $\mathrm{w}$ formie pisanej ${ }^{52}$.

Tendencja dominująca we współczesnej praktyce międzynarodowej jest wykorzystywanie wód, w tym rzek o znaczeniu międzynarodowym, do celów nieżeglugowych (np. przemysł, rolnictwo, produkcja energii) ${ }^{53}$. Różne sposoby nieżeglugowego wykorzystywania wód oraz rozwój regulacji prawnych w tym zakresie wpłynęły na proces głębokiej ewolucji międzynarodowego prawa rzecznego, doprowadzajac do ukształtowania się i rozwoju międzynarodowego prawa zasobów wodnych, które obejmuje nie tylko regulacje dotyczące żeglugi na rzekach międzynarodowych, lecz także nieżeglugowego wykorzystanie wód powierzchniowych i gruntowych ${ }^{54}$. J. Menkes uważa w związku z tym, że takie wykorzystanie wód i proces tworzenia regulacji prawnych $\mathrm{w}$ tej dziedzinie uzasadniaja postawienie tezy, że $\mathrm{z}$ prawa międzynarodowego $\mathrm{i} \mathrm{z}$ prawa środowiska wyłoniły się główne zarysy międzynarodowego prawa zasobów wodnych. Autor podkreśla, że przedmiotem regulacji międzynarodowego prawa zasobów wodnych sa i będą wszystkie fakty i stosunki prawne związane ze zlewiskiem wodnym ${ }^{55}$.

Ewolucję tę dobrze ilustruja prace Stowarzyszenia Prawa Międzynarodowego (International Law Association), a w jego ramach zwłaszcza Committee on the Use of the Waters of International Rivers. Prace te oznaczaja odejście od instytucji rzeki międzynarodowej i pojawienie się nowej kategorii pojęciowej,

urządzeń technicznych oraz swobody przewożenia towarów i pasażerów między państwami nadbrzeżnymi oraz między państwem nadbrzeżnym a morzem otwartym. Szerzej zob.: W. Czapliński, A. Wyrozumska, Prawo międzynarodowe publiczne. Zagadnienia systemowe, Warszawa 1999, s. 136.

${ }_{50}$ Komisja do Spraw Żeglugi po Renie, Międzynarodowa Komisja Dunaju.

51 J. Menkes, op. cit., s. 56. Zob. też R.-J. Dupuy, L'océan partagé, Paris 1979, s. 19 i n.

52 J. Pieńkos, Prawo międzynarodowe publiczne, Kraków 2004, s. 602.

${ }^{53}$ Problematykę tę szeroko omawia S. Wajda, Żeglowne a nieżeglowne wykorzystanie wód śródladowych ze szczególnym uwzględnieniem rzek międzynarodowych, „Przegląd Stosunków Międzynarodowych" 1980 , nr 6, s. 71 i n.

${ }^{54} \mathrm{O}$ problematyce tej pisze szeroko S. McCaffrey, The Law of International Watercourses, Oxford 2007.

55 J. Menkes, op. cit., s. 90. 
którą jest zlewisko (dorzecze) międzynarodowe (ang. international drainage basin, fr. bassin de drainage international), wyznaczone naturalnymi działami wodnymi, bez względu na granice i podziały polityczne ${ }^{56}$. Ta nowa kategoria pojęciowa pojawiła się w rezolucji o użytkowaniu wód rzek międzynarodowych przyjętej przez ILA na konferencji w Nowym Jorku w 1958 r. Została ona zdefiniowana $\mathrm{w}$ art. II wspomnianych już reguł helsińskich, który określa zlewisko międzynarodowe jako ,rejon geograficzny rozciąający się na terytorium dwóch lub więcej państw, ograniczony liniami podziału kilku systemów wodnych, rozumianych jako wody powierzchniowe i podziemne płynące do wspólnego ujścia" ${ }^{57}$. W części 4 (art. XII-XIX) tych reguł znajdujemy szczegółowe postanowienia odnoszące się do uprawiania i wolności żeglugi na rzekach i jeziorach zlewiska.

Podobne do zlewiska międzynarodowego pojęcie zostało zawarte w opracowanym przez Komisję Prawa Międzynarodowego projekcie Konwencji o prawie nieżeglugowego użytkowania międzynarodowych cieków wodnych, która została uchwalona 21 maja $1997 \mathrm{r} .{ }^{58}$ Znaczenie tego dokumentu sprowadza się zwłaszcza do tego, że zdefiniowano $\mathrm{w}$ nim pojęcie międzynarodowego cieku wodnego (ang. international watrecourse, fr. cours d'eau international) i wprowadzono zasady nieżeglugowego wykorzystywania takich cieków, jak również powiązano międzynarodowe prawo cieków wodnych z prawem ochrony środowiska ${ }^{59}$. Definicja sformułowana w art. 2 tej Konwencji stanowi, że: „,międzynarodowym ciekiem wodnym jest znajdujący się na terytorium różnych państw system wód powierzchniowych i gruntowych, które z racji fizycznych powiązań tworza jednolitą całość i w normalnych warunkach płyna do wspólnego ujścia". Konwencyjne określenie międzynarodowego cieku wodnego pozwoliło objąć regulacjami całość wód, niezależnie od poziomu ich występowania bądź zalegania $^{60}$. Postanowienia Konwencji zobowiązuja państwa dysponujące ciekiem wodnym do jego wykorzystywania w sposób racjonalny i sprawiedliwy. Powinny one $\mathrm{w}$ dobrej wierze współpracować ze sobą na zasadach poszanowania ich suwerenności, równości oraz integralności terytorialnej ${ }^{61}$. Warto dodać, że

\footnotetext{
${ }^{56} \mathrm{Na}$ temat tych prac ILA zob. S. M. A. Salman, The Helsinki Rules, the UN Watercourses Convention and the Berlin Rules: Perspectives on International Water Law, „Water Resources Development" 23, 2007, nr 4, s. 629.

${ }^{57}$ The Helsinki Rules on the Uses of the Waters of International Rivers, International Law Association (1966) Report of the Fifty-Second Conference, Helsinki, s. 447 i n.

${ }^{58}$ UN Convention on the Law of Non-Navigational Uses of International Watercourses, UN Doc. A/51/8609. Konwencja ta nie weszła jeszcze w życie (wymaga 35 ratyfikacji, Polska nie podpisała i nie związała się tą konwencją). O pracach Komisji Prawa Międzynarodowego w tym zakresie pisze G. J. Cano, The Development of the Law of International Water Resources and the Work of the International Law Commission, „Water International” 14, 1989, s. 167 i n.

${ }^{59}$ L. Caflish, Regulation of the Uses of International Watercourses, w: S. M. A. Salman, L. Boisson de Chazournes (red.), International Watercourses - Enhancing Cooperation and Managing Conflict, World Bank Technical Paper, t. 14, 1998, s. 15 i n.

${ }^{60}$ S. M. A. Salman, op. cit., s. 631 i n.; S. C. McCaffrey, The Codification of Universal Norms: A Means to Promote Cooperation and Equity?, w: L. Boisson de Chazournes, C. Leb, M. Tignino (red.), International Law and Freshwater: The Multiple Challenges International Law and Freshwater, Cheltenham 2013, s. 133-134.

${ }^{61}$ M. M. Kenig-Witkowska, Międzynarodowe prawo środowiska. Wybrane zagadnienia systemowe, Warszawa 2011, s. 293 i n.
} 
w art. 20 Konwencji znajdujemy jeszcze jedną kategorię pojęciową, szerszą od międzynarodowego cieku wodnego. Jest to pojęcie ekosystemu międzynarodowych cieków wodnych ${ }^{62}$. Sygnalizując najważniejsze postanowienia tej Konwencji, pamiętać należy o postanowieniach wcześniejszej, przygotowanej pod auspicjami Europejskiej Komisji Gospodarczej ONZ, Konwencji o ochronie i użytkowaniu cieków transgranicznych i jezior międzynarodowych z $1992 \mathrm{r}^{63}$ $\mathrm{W}$ art. 1 znajdujemy następującą definicję wód transgranicznych: „wody transgraniczne oznaczaja każde powierzchniowe lub podziemne wody, które tworzą i przecinaja granice między dwoma lub więcej państwami lub znajduja się na takich granicach; jeżeli wody transgraniczne wpływają bezpośrednio do morza, to ich zasięg kończy się na linii prostej, łączącej punkty linii niskiej wody na ich brzegach, poprzecznej do ujścia cieku transgranicznego". Konwencja nakłada na państwa strony obowiązek podejmowania działań w celu wyeliminowania jakichkolwiek niekorzystnych skutków dla środowiska, wynikających z działalności na wodach śródlądowych ${ }^{64}$.

Sygnalizując problematykę rozwoju międzynarodowego prawa zasobów wodnych w kontekście wolności żeglugi, należy pamiętać o najnowszych pracach Stowarzyszenia Prawa Międzynarodowego w tym zakresie. Jako rozwinięcie postanowień zapisanych $\mathrm{w}$ regułach helsińskich na konferencji Stowarzyszenia w $2004 \mathrm{r}$. uchwalone zostały tzw. reguły berlińskie, których część IX (art. 43-49) poświęcona jest problematyce żeglugi na transgranicznych ciekach wodnych ${ }^{65}$. Sformułowana w art. 43 pkt 3 definicja cieku wodnego obejmuje: „rzekę, jezioro lub inny zbiornik wodny, na którym możliwa jest żegluga z jednego państwa nadbrzeżnego do drugiego lub do morza otwartego". Podobnie jak w postanowieniach art. XII-XIX reguł helsińskich, znajdujemy tu postanowienia odnoszące się do uprawiania i wolności żeglugi na rzekach i jeziorach zlewiska. Postanowienia te (zarówno berlińskie, jak i helsińskie) nawiązuja do omówionych wyżej klasycznych rozwiązań konwencyjnych odnoszących się do wolności żeglugi na rzekach międzynarodowych ${ }^{66}$. Chociaż gwarantuja państwom nadbrzeżnym wolność żeglugi na transgranicznych ciekach wodnych, nie przewidują one jednak powszechnej wolności żeglugi na tych wodach. Do uprawiania takiej żeglugi potrzebne są szczegółowe regulacje konwencyjne $^{67}$.

mgr Andrzej Gadkowski

Uniwersytet Genewski, Szwajcaria

oraz Uniwersytet im. Adama Mickiewicza w Poznaniu

andrzej.gadkowski@unige.ch

62 Ang. ecosystems of international watercourses, fr. ecosystème des cours d'eau internationaux.

${ }^{63}$ UN Convention on the Protection and Use of Transboundary Waters and International Lakes, tekst: UNTS, vol. 1936, s. 269. Konwencja weszła w życie 6 października 1996 r. (dla Polski 13 czerwca 2000 r.; tekst polski: Dz. U. 2003, Nr 78, poz. 703).

${ }^{64}$ M. N. Shaw, Prawo międzynarodowe, Warszawa 2006, s. 467 i n.

${ }^{65}$ ILA Berlin Rules; tekst: International Law Association (2004) Report of the Seventy-First Conference, s. 334 i n.

${ }^{66}$ Szersze uwagi na ten temat zob. np. S. M. A. Salman, op. cit., s. 629 i n.

${ }^{67} \mathrm{Na}$ możliwość zawierania takich umów wskazuje art. 44 pkt 1 Reguł berlińskich; zob. też komentarz do art. 44 -ILA (2004) Report of the Seventy-First Conference, s. 392. 


\section{TREATY BASIS OF THE FREEDOM OF NAVIGATION ON INTERNATIONAL RIVERS FROM THE PERSPECTIVE OF INTERNATIONAL LAW APPLICABLE TO WATER RESOURCES}

\section{Summary}

The aim of this paper is to present the issue of the freedom of navigation on international rivers in light of international law and international practice. An analysis of relevant provisions of pertinent treaties which determine the scope of that freedom and the rules that govern its use leads to a conclusion that no universal principle of freedom of navigation on international rivers has been formulated, nor can be found in the norms of customary international law. This subject is presented from the perspective of contemporary international law applicable to water resources, which is linked to international environmental law. Its regulations, and in particular the 1997 Convention on the Law of the Non-Navigational Uses of International Watercourses, do not provide for such universal freedom of navigation on transboundary watercourses. Similar approaches may be found in the work of the International Law Commission, for example in its 1966 Helsinki Rules and 2004 Berlin Rules. 
Copyright of Journal of Law, Economics and Sociology is the property of Faculty of Law and Administration of Adam Mickiewicz University in Poznan and its content may not be copied or emailed to multiple sites or posted to a listserv without the copyright holder's express written permission. However, users may print, download, or email articles for individual use.

Właścicielem praw autorskich do „Ruchu Prawniczego, Ekonomicznego i Socjologicznego” jest Wydział Prawa i Administracji Uniwersytetu im. Adama Mickiewicza w Poznaniu. Zawartość czasopisma nie może być kopiowana, przesyłana do innych stron internetowych bądź zamieszczana na blogach bez pisemnej zgody wydawcy. Niemniej artykuły można drukować, kopiować lub przesyłać w formie elektronicznej na własny użytek. 